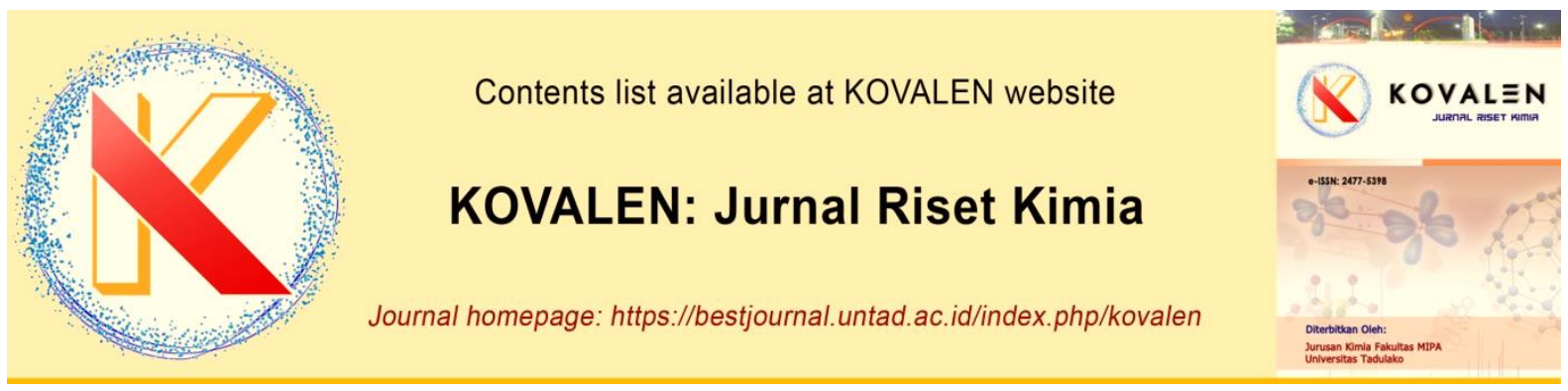

\title{
Aktivitas Antioksidan Akar Bawang Merah Lokal Palu (Allium cepa Var Aggergatum L.) dengan Berbagai Kepolaran Pelarut
}

\section{[Antioxidant Activity of Local Shallot Roots (Allium cepa Var Aggregatum L.) in Palu City with Various Solvent]}

\author{
Nur Faidah`, Nurhaeni, Ahmad Ridhay, Jusman, Abd. Rahman Razak, Syaiful Bahri \\ Jurusan Kimia, Fakultas Matematika dan Ilmu Pengetahuan Alam, Universitas Tadulako, \\ Jl. Soekarno-Hatta Km. 9, Kampus Bumi Tadulako, Palu, Indonesia \\ *Corresponding author: nurfaidahmamase62846@gmail.com
}

\begin{abstract}
Research on the antioxidant activity of the local onion roots of Palu (Allium cepa Var Aggregatum L.) with various polarity solvents has been carried out. This study aims to determine the potential of Palu local shallot root extract as an antioxidant and determine the $\mathrm{IC}_{50}$ value of the Palu local shallot root antioxidant activity. The method applied in this research is maceration using $n$-hexane, ethyl acetate, and ethanol. The extracts from each solvent were tested for their antioxidant activity by the DPPH method. The results of the study showed that the $\mathrm{IC}_{50}$ value in n-hexane extract, ethyl acetate extract, and ethanol extract were $579.98 \mathrm{ppm}, 518.28 \mathrm{ppm} 315.83 \mathrm{ppm}$ and as a comparison used ascorbic acid obtained $\mathrm{IC}_{50}$ of $53.69 \mathrm{ppm}$. Based on the results obtained, the best antioxidant activity is in polar solvents (ethanol extract) compared to other solvents.
\end{abstract}

Keywords: Antioxidants, roots, Palu local shallots, Allium cepa Var Aggregatum L.

ABSTRAK. Telah dilakukan penelitian tentang aktivitas antioksidan akar bawang merah lokal Palu (Allium cepa Var Aggregatum L.) dengan berbagai kepolaran pelarut. Penelitian ini bertujuan untuk mengetahui komponen metabolit sekunder yang terdapat pada ekstrak akar bawang merah dengan berbagai kepolaran pelarut dan menentukan nilai $I C_{50}$ aktivitas antioksidan akar bawang merah lokal Palu. Metode yang diterapkan dalam penelitian ini adalah maserasi dengan menggunakan pelarut $n$-heksan, pelarut etil asetat dan pelarut etanol. Ekstrak dari masing-masing pelarut diuji aktivitas antioksidannya dengan metode DPPH. Hasil penelitian menyatakan bahwa nilai I $_{50}$ pada ekstrak $n$-heksan, ekstrak etil asetat, dan ektrak etanol yaitu 579,98 ppm, 518,28 ppm 315,83 ppm dan sebagai pembanding digunakan asam askorbat diperoleh $I_{50}$ 53,69 ppm. Berdasarkan hasil yang diperoleh, aktivitas antioksidan terbaik adalah pada pelarut yang bersifat polar (ekstrak etanol) dibandingkan dengan pelarut lainnya.

Kata Kunci: Antioksidan, akar, bawang merah lokal Palu, Allium cepa Var Aggregatum L.

Riwayat artikel: Diterima 24 September 2019, Disetujui 28 November 2020

Cara sitasi: Faidah, N., Nurhaeni., Ridhay, A., Jusman., Razak, A R., \& Bahri, S. (2020). Aktivitas Antioksidan Akar Bawang Merah Lokal Palu (Allium cepa Var Aggergatum L.) dengan Berbagai Kepolaran Pelarut. KOVALEN: Jurnal Riset Kimia, 6(3): $198-205$. DOI: https://doi.org/10.22487/kovalen.2020.v6.i3.13662

\section{LATAR BELAKANG}

Bawang merah (Allium cepa Var Aggregatum L.) merupakan salah satu varietas unggul di Lembah Palu dengan hasil produksi pada tahun 2016 dengan luas panen 1.804 ha, dengan produksi $9.088,30$ ton. Dari data 
tersebut menunjukkan bahwa komoditas bawang merah di Sulawesi Tengah memiliki kenaikan yang baik dibandingkan tahun-tahun sebelumnya (BPS, 2017). Limbah akar bawang merah juga sangat banyak, akan tetapi masyarakat belum mengetahui manfaat dari limbah tersebut dan hanya dibuang begitu saja.

Bawang merah biasanya digunakan sebagai bumbu penyedap masakan dan kebutuhan pokok untuk bahan baku industri makanan (Ete \& Alam, 2009), selain itu, juga dapat dimanfaatkan sebagai obat tradisional karena adanya senyawa alliin dan allisin yang bersifat antibakteri (Anabarwatil \& Yudono, 2003). Kadar flavonoid yang tinggi pada umbi bawang merah menjadikan bawang merah sebagai antioksidan yang baik untuk menghambat radikal bebas. Hal ini diyakini bahwa bawang merah mengandung komponen kimia yang mempunyai efek antiinflamasi, antikanker, antikolestrol, dan antioksidan seperti kuersetin (Galeone et al., 2006).

Antioksidan adalah senyawa yang mampu menghambat oksigen reaktif dan radikal bebas dalam tubuh dengan cara mendonorkan satu atau lebih elektron kepada radikal bebas sehingga menjadi molekul yang normal kembali dan dapat mengentikan akibat kerusakan yang ditimbulkan (Sasikumar et al., 2009). Dalam keadaan normal (saat istirahat) sistem pertahanan dalam tubuh, antioksidan dapat secara mudah mengatasi radikal bebas yang mucul (Capelli \& Cysewski, 2006). Penelitian senyawa antioksidan dari tumbuhan banyak dikembangkan saat ini, seperti senyawa fenolik, terutama flavonoid (Kumar \& Pandey, 2013). Beberapa tanaman yang berasal dari Famili Liliciae memiliki aktivitas antioksidan, seperti ekstrak kulit bawang merah (Allium ascalonicum L.) memiliki nilai $I C_{50} 15,44$ ppm yang membuktikan bahwa kulit bawang merah termasuk golongan antioksidan yang sangat kuat (Mardiah et al., 2017).

Ekstraksi senyawa antioksidan dari tanaman umumnya menggunakan jenis pelarut dengan tingkat kepolaran yang berbeda, seperti $n$-heksan berisfat non polar, etil asetat bersifat semi polar, dan etanol bersifat polar. Penggunaan kepolaran pelarut yang berbeda saat ekstraksi sangat berguna untuk mendapatkan ekstrak dengan aktivitas antioksidan yang tinggi (Lestario et al., 2005). Hasil uji aktivitas antioksidan yang dilakukan (Amin, 2015), umbi bawang lanang (Allium sativum) dengan menggunakan fraksi $n$ heksan, fraksi etil asetat dan etanol memiliki nilai $I C_{50}$ secara berturut-turut yaitu 7249,25 ppm, 7,27 ppm, dan 13,85 ppm

Aktivitas antioksidan umumnya ditentukan dengan metode DPPH, yaitu metode yang pengujiannya didasarkan pada kemampuan antioksidan menangkal radikal bebas dengan mendonorkan atom hidrogen. Metode DPPH menggunakan senyawa radikal 1,1-difenil-2pikrihidrasil (Triyem, 2010). Penggunaan metode DPPH memiliki kelebihan yaitu sederhana, cepat, dan tidak membutuhkan banyak reagen. Hasil pengukuran yang dihasilkan dengan metode DPPH menunjukkan aktivitas antioksidan secara umum, tidak berdasarkan jenis radikal yang dihambat (Putranti, 2013). Pengukuran dapat dilakukan dengan menggunakan spektrofotometer dengan panjang gelombang $517 \mathrm{~nm}$. Dengan adanya radikal bebas, maka struktur kimia 1,1difenil-pikrihidrazil (yang berwarna ungu menjadi) 1,1-2-pikirihidrazin (yang berwarna kuning) (Shekhar \& Goyal, 2014). Penelitian ini memberikan informasi tentang jenis ekstrak 
akar bawang merah lokal Palu yang berpotensi sebagai salah satu sumber antioksidan.

\section{METODE PENELITIAN}

\section{Bahan dan Peralatan}

Bahan yang digunakan dalam penelitian ini adalah akar bawang merah lokal Palu (Allium cepa Var Aggregatum L.) Bahan-bahan lain yang digunakan yaitu $n$-heksan pa, etanol $96 \%$, etil asetat pa, asam klorida pekat, $\mathrm{FeCl}_{3}$ $5 \%$, asam sulfat pekat, asam askorbat, DPPH, serbuk magnesium, akuades, pereaksi dragendorff, anhidrat asetat, kloroform, aluminium foil, dan kertas saring.

Alat yang digunakan dalam penelitian ini adalah blender, ayakan 80 mesh, neraca analitik, talam aluminium, rotary vakum evaporator, alat penyaring vakum, Spektrofotometer UV-Vis PerkinElmer L850, kuvet, dan alat-alat gelas laboratorium lainnya.

\section{Prosedur Penelitian}

\section{Preparasi sampel}

Akar bawang merah dipisahkan dari umbinya, dibersihkan, dirajang kemudian dikering anginkan pada suhu ruang, setelah itu dihaluskan menggunakan blender lalu diayak dengan ayakan 80 mesh untuk mendapatkan tepung akar bawang merah.

\section{Ekstraksi akar bawang}

Ekstraksi dilakukan dengan metode maserasi secara bertahap dengan menggunakan tiga jenis pelarut. Ekstraksi pertama digunakan pelarut $n$-heksan dengan cara menimbang tepung akar bawang merah sebanyak $100 \mathrm{~g}$, selanjutnya dimasukkan ke dalam erlenmeyer $1000 \mathrm{~mL}$ lalu ditambahkan $500 \mathrm{~mL} n$-heksan (perbandingan pelarut dan sampel 1:5). Campuran disimpan selama 48 jam sambil sesekali diaduk, kemudian disaring dengan penyaring vakum. Filtrat yang diperoleh pelarutnya dipisahkan menggunakan rotari vakum evaporator sehingga didapatkan ekstrak kental akar bawang merah. Residu yang diperoleh dikering-anginkan, lalu dimasukkan ke dalam erlenmeyer untuk diekstrak kembali dengan pelarut etil asetat dan pelarut etanol dengan perlakuan yang sama pada pelarut $n$ heksan (Nurhaeni et al., 2019).

\section{Uji kualitatif komponen ekstrak (Harborne, 1987)}

\section{a. Uji flavonoid}

$1 \mathrm{~mL}$ sampel ditambahkan dengan 0,5 gram serbuk magnesium dan 10 tetes $\mathrm{HCl}$ pekat (pereaksi shinoda), bila bereaksi positif akan menghasilkan larutan berwarna jingga, merah muda atau merah.

\section{b. Uji saponin}

Dimasukan $1 \mathrm{~mL}$ sampel ke dalam tabung reaksi kemudian dipanaskan 2-3 menit. Dinginkan, setelah dingin dikocok dengan kuat. Uji positif ditandai dengan terbentuknya busa yang stabil selama 510 menit dan tidak hilang pada saat penambahan 1 tetes $\mathrm{HCl} 2 \mathrm{~N}$.

\section{c. Uji tanin}

Sebanyak $1 \mathrm{~mL}$ sampel ditambahkan larutan $\mathrm{FeCl}_{3} 5 \%$ bila bereaksi positif akan menghasilkan warna hijau kehitaman, merah, ungu, biru atau hitam yang kuat.

\section{d. Uji alkaloid}

Memasukkan 1,0 mL sampel ke dalam tabung reaksi kemudian ditambahkan 2-3 tetes pereaksi dragendrof. Uji positifnya ditandai dengan terbentuknya endapan merah jingga.

\section{e. Uji terpenoid dan steroid}

Memasukkan $1 \mathrm{~mL}$ sampel ke dalam tabung reaksi lalu ditambahkan $2 \mathrm{~mL}$ kloroform kemudian ditambahkan 10 tetes anhidrat asetat dan 3 tetes asam sulfat 
pekat. Uji positif ditandai dengan terbentuknya larutan berwarna hijau atau biru.

\section{Pengujian aktivitas antioksidan dengan metode DPPH (Molyneux, 2003)}

Ekstrak $n$-heksan, etil asetat dan etanol masing-masing ditimbang sebanyak $25 \mathrm{mg}$ dan dimasukkan ke dalam labu ukur $25 \mathrm{~mL}$ selanjutnya dilarutkan dengan etanol dan ditepatkan volume hingga diperoleh konsentrasi 1000 ppm. Selanjutnya ambil masing-masing larutan tersebut sebanyak 0,1 ; 0,$3 ; 0,5 ; 0,7 ;$ dan $0,9 \mathrm{~mL}$, lalu diencerkan kembali dengan etanol dalam labu ukur $10 \mathrm{~mL}$ sehingga diperoleh larutan ekstrak dengan konsentrasi (10, 30, 50, 70 dan 90 ppm). Untuk penentuan aktivitas antioksidan masingmasing konsentrasi dipipet sebanyak $0,2 \mathrm{~mL}$ larutan sampel dengan pipet mikro dan masukan ke dalam vial, lalu tambahkan $3,8 \mathrm{~mL}$ larutan DPPH $50 \quad \mu \mathrm{M}$. Campuran dihomogenkan dan dibiarkan selama 30 menit ditempat gelap, serapan diukur dengan spektrofotemeter UV-Vis pada panjang gelombang $517 \mathrm{~nm}$. Aktivitas antioksidan sampel ditentukan berdasarkan besarnya hambatan serapan radikal DPPH melalui perhitungan presentasi inhibisi serapan DPPH (persamaan 1).

$\%$ inhibisi $=\frac{A_{\text {Kontrol }}-A_{\text {Sampel }}}{A_{\text {Kontrol }}} \times 100 \% \ldots \ldots . .(1)$

Nilai konsentrasi sampel dan penghambatan ekstrak, diplot masing-masing sumbu $x$ dan $y$ pada persamaan regresi linier $y=a(x)+b$, persamaan tersebut digunakan untuk mencari nila $I_{50}$ (inhibitor concentration $50 \%$ ) masingmasing sampel dengan menyatakan nilai $y$ sebesar 50 dan nilai $\mathrm{x}$ sebagai $I C_{50} . \quad I_{50}$ menyatakan konsentrasi larutan sampel yang dibutuhkan untuk mereduksi DPPH sebesar $50 \%$.

\section{HASIL DAN PEMBAHASAN}

\section{Ekstrak Akar Bawang Merah Lokal Palu}

Ekstrasi akar bawang merah lokal Palu dalam penelitian ini menggunakan metode maserasi. Pelarut yang digunakan dalam peneltian ini adalah $n$-heksan, etil asetat dan etanol. Pada tahap ekstraksi ini dimulai dari jenis pelarut yang non polar, dilanjutkan dengan semi polar dan pelarut polar. Pada proses maserasi digunakan variasi pelarut karena senyawa aktif akar bawang merah Lokal Palu belum diketahui sifat kepolarannya.

Ekstrak akar bawang merah lokal Palu yang dihasilkan untuk $n$-heksan berwarna kuning pucat, ekstrak etil asetat berwarna kuning dan untuk ekstrak etanol berwarna kuning kecoklatan. Ekstrak yang diperoleh dari maserasi di saring menggunakan corong buchner. Filtrat akar bawang merah lokal Palu dipekatkan dengan rotary evaporator untuk menghilangkan pelarutnya, hasil yang diperoleh ekstrak kental $n$-heksan berwarna kuning pudar dengan rendemen $0,46 \%$, ekstrak kental etil asetat berwarna coklat dengan rendemen $0,57 \%$ sedangkan ekstrak kental etanol berwarna coklat kehitaman dengan rendemen $0,68 \%$. Rendemen yang dihasilkan dapat jadi dasar asumsi akan banyaknya komponen bioaktif yang terkandung didalamnya.

\section{Hasil Skrining Fitokimia}

Hasil pengujian yang dilakukan menunjukkan adanya golongan senyawa metabolit sekunder seperti flavonoid, saponin, tanin, alkaloid, terpenoid dan steroid (Tabel 1). Ekstrak $n$-heksan menunjukkan reaksi positif pada uji golongan senyawa alkaloid ditandai 
dengan endapan merah jingga. Untuk ekstrak etil asetat menunjukkan reaksi positif pada senyawa flavonoid ditandai dengan warna merah muda tua, uji senyawa saponin ditandai dengan adanya busa dan alkaloid positif ditandai dengan endapan merah jingga. Sedangkan untuk ekstrak etanol positif mengandung senyawa flavonoid, saponin, tanin dan alkaloid, untuk flavonoid berwarna merah muda, senyawa saponin ditandai dengan adanya busa, senyawa tanin positif ditandai dengan berubahnya warna menjadi hijau kehitaman dan untuk alkaloid ditandai dengan adanya endapan merah jingga.

Tabel 1. Hasil skrining fitokimia dari ekstrak akar bawang mera lokal Palu (Allium cepa Var Aggregatum L.)

\begin{tabular}{|c|c|c|c|}
\hline \multirow{2}{*}{$\begin{array}{l}\text { Golongan } \\
\text { Senyawa }\end{array}$} & \multicolumn{3}{|c|}{ Jenis Pelarut } \\
\hline & $\begin{array}{c}n- \\
\text { heksan }\end{array}$ & $\begin{array}{c}\text { Etil } \\
\text { Asetat }\end{array}$ & Etanol \\
\hline Flavonoid & - & +++ & ++ \\
\hline Saponin & - & +++ & ++ \\
\hline Tanin & - & - & +++ \\
\hline Alkaloid & + & + & +++ \\
\hline $\begin{array}{l}\text { Steroid dan } \\
\text { Triterpenoid }\end{array}$ & - & - & \\
\hline $\begin{array}{l}\text { Keterangan: } \\
(+++)=\text { Sangat } \\
(+) \quad=\text { lemah }\end{array}$ & lat & $\begin{array}{c}(++)=\mathrm{kL} \\
(-)=\mathrm{T}\end{array}$ & rdeteksi \\
\hline
\end{tabular}

Aktivitas antioksidan pada ekstrak bawang merah lokal Palu dilakukan dengan menggunakan metode DPPH (1,1-difenil-2pikrihidrazil). DPPH berperan sebagai radikal bebas yang akan bereaksi dengan antioksidan membentuk DPPH-H (1,1-difenil-2-pikrihidazin) dan radikal antioksidan. Senyawa radikal bebas biasanya digunakan untuk mengetahui aktivitas penangkal radikal bebas.

Nilai $I C_{50}$ diperoleh dari data $\%$ inhibisi pada masing-masing pelarut dengan cara memplotkan nilai perhitungan ke dalam persamaan linear dengan konsentrasi (ppm) sebagai axsis $(X)$ dan nilai presen inhibisi sebagai ordinat $(\mathrm{Y})$, nilai $I C_{50}$ dari perhitungan pada saat $\%$ inhibisi sebesar $50 \%$ dengan persamaan $\mathrm{Y}=\mathrm{aX}+\mathrm{b}($ Gambar $1-$ Gambar 4).

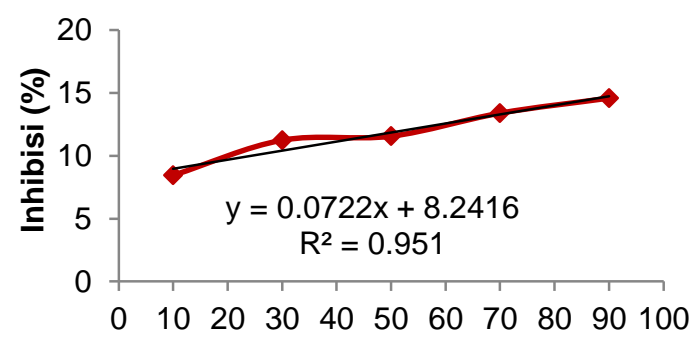

Konsentrasi (ppm)

Gambar 1. Kurva hubungan konsentrasi ekstrak n-heksan terhadap \%inhibisi

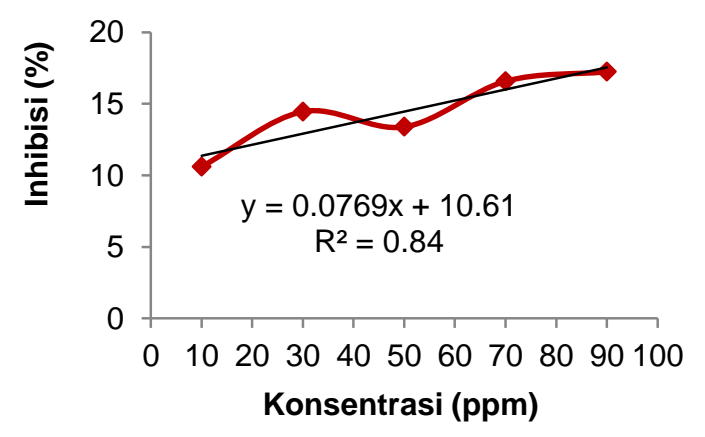

Gambar 2. Kurva hubungan konsentrasi ekstrak etil asetat terhadap \%inhibisi

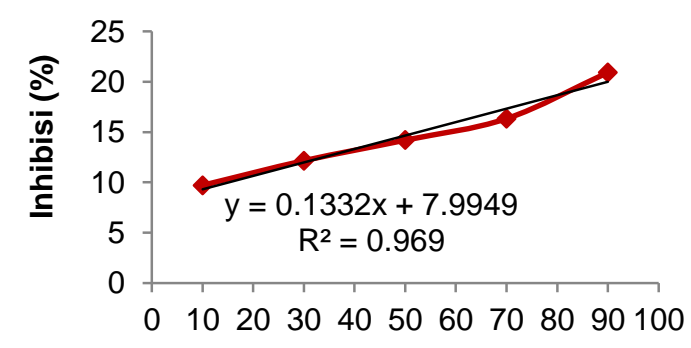

Konsentrasi (ppm)

Gambar 3. Kurva hubungan konsentrasi ekstrak etanol terhadap \%inhibisi

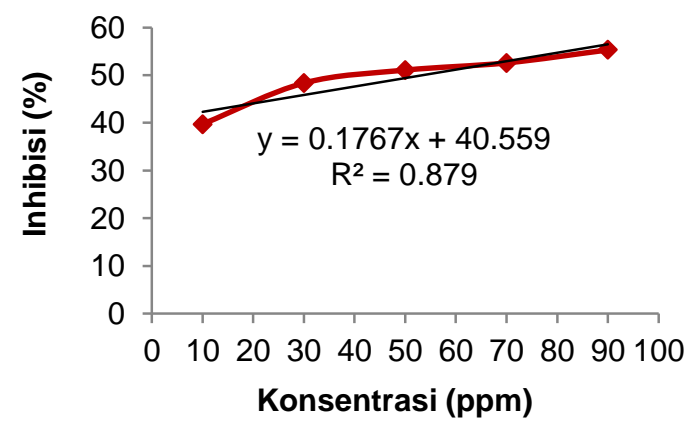

Gambar 4. Kurva hubungan konsentrasi vitamin $\mathrm{C}$ terhadap \%inhibisi 
Ekstrak etanol memiliki nilai $I C_{50}$ sebesar 315,83 ppm lebih kuat dibandingkan dengan ekstrak $n$-heksan dan ekstrak etil asetat (Gambar 5) dengan rendemen yang diperoleh yaitu $0,68 \%$. Aktivitas antioksidan terjadi karena bereaksinya molekul difenilpkrihidrazil dengan atom hidrogen sehingga terbentuknya difenilpkrihidrazin, yang dapat dilihat pada saat penambahaan DPPH dari ungu menjadi kuning. Antioksidan alami dapat ditemukan pada tanaman, senyawa yang dapat berperan sebagai antioksidan alami salah satunya adalah flavonoid dan fenolik yang bersifat polar (Andriani et al., 2011).

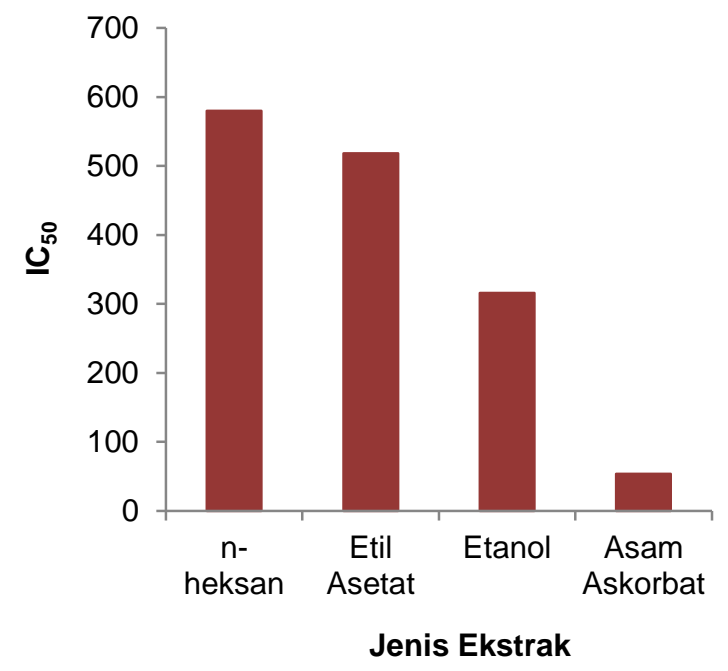

Gambar 5. Diagram Aktivitas antioksidan ekstrak $n$-heksan, ekstrak etil asetat, ekstrak etanol, dan asam askorbat

Hasil skrining fitokimia menunjukkan bahwa ekstrak etanol banyak mengandung senyawa antioksidan yaitu flavonoid, saponin, alkaloid dan tanin. Salah satu senyawa antioksidan yang paling berpengaruh adalah senyawa tanin karena dapat dilihat pada saat pengujian metabolit sekunder senyawa tanin berwarna hijau kehitaman dimana tanin merupakan senyawa golongan polifenol yang banyak terdapat gugus $-\mathrm{OH}$ yang dapat meredam radikal bebas. Radikal bebas yang terbentuk pada senyawa tanin akan terstabilkan oleh resonansi sehingga dapat berfungsi sebagai antioksidan yang efektif (Wijaya, 2011).

Pada ekstrak etil asetat nilai $I C_{50}$ yang diperoleh sebesar 518,28 ppm (Gambar 5). Aktivitas antioksidan pada ekstrak etil asetat bersifat lemah dibandingkan dengan ekstrak etanol, hal ini dikarenakan rendemen yang dihasilkan lebih sedikit yaitu $0,57 \%$. Akan tetapi senyawa yang tersari pada saat pengujian metabolit sekunder adalah flavonoid, saponin dan alkaloid. Menurut (Gurav et al., 2007), senyawa flavonoid memiliki aktivitas antioksidan karena adanya gugus $-\mathrm{OH}$ yang dapat melepaskan proton dalam bentuk ion hidrogen. Ion hidrogen yang bermuatan positif menyebabkan elektron atau radikal bebas pada atom nitrogen DPPHmenjadi tereduksi (Arazo et al., 2011).

Uji aktivitas antioksidan ekstrak $n$-heksan diperoleh $/ C_{50}$ sebesar 579,98 ppm (Gambar 5). Aktivitas antioksidan ekstrak $n$-heksan terhadap sampel akar bawang merah lokal palu bersifat sangat lemah. Lemahnya aktivitas antioksidan dapat dilihat dari rendemen yang dihasilkan hanya sedkit yaitu $0,46 \%$ selain itu juga pada saat pengujian fitokimia senyawa yang tersari hanya mengandung senyawa alkaloid saja.

Bila dibandingkan hasil penelitian dari (Amin, 2015), umbi bawang lanang (Allium sativum), aktivitas antiokisdannya lebih tinggi pada fraksi etil asetat dengan nilai $I C_{50}$ sebesar 7,27 ppm, diikuti dengan etanol nilai $I C_{50}$ sebesar $13,85 \mathrm{ppm}$ dan fraksi $n$-heksan nilai $I_{50}$ sebesar $7249,25 \mathrm{ppm}$. Perbedaan tersebut dikarenakan pada saat pengujian fitokimia ekstrak etil asetat hanya mengandung senyawa flavonoid, saponin dan alkaloid sedangkan 
pada ekstrak Allium sativum pada fraksi etil asetat uji fitokimia yang tersari lebih banyak yaitu falvonoid, saponin, tanin dan polifenol, steroid dan triterpenoid.

Nilai $I C_{50}$ dari asam askorbat diperoleh 53,69 ppm lebih kuat aktivitas antioksidannya dibandingkan dengan semua ekstrak Allium cepa Var Aggregatum L. Hal ini dikarenakan asam askorbat merupakan antioksidan kuat yang mampu menjaga kesehatan sel, meningkatkan penyerapan asupan zat besi dan memperbaiki sistem kekebalan tubuh (Kumalaningsih, 2006).

Nilai $I C_{50}$ ekstrak etanol $>$ ekstrak etil asetat > ekstrak $n$-heksan karena pada ekstrak etanol mengandung metabolit sekunder yaitu flavonoid, saponin, tanin dan alkaloid, untuk ekstrak etil asetat mengandung senyawa falvonoid, saponin dan alkaloid sedangkan pada ekstrak $n$-heksan hanya mengandung alkaloid saja.

\section{KESIMPULAN}

Hasil uji fitokimia ekstrak $n$-heksan mengandung senyawa alkaloid, ekstrak etil asetat mengandung senyawa flavonoid, saponin, alkaloid dan ekstrak etanol mengandung senyawa flavonoid, saponin, tanin dan alkaloid. $I C_{50}$ ekstrak $n$-heksan, ekstrak etil asetat dan ekstrak etanol berturutturut adalah 579,98 ppm, 518,28 ppm dan 315,83 ppm. Berdasarkan data tersebut, maka ekstrak etanol akar bawang merah lokal Palu memiliki aktivitas antioksidan tertinggi dibandingkan ekstrak lainnya.

\section{DAFTAR PUSTAKA}

Amin, S. (2015). Uji Aktivitas Antioksidan Umbi Bawang Lanang (Allium sativum) Terhadap Radikal Bebas Dpph (1,1Difenil-2-Pikrihidrazil. Jurnal Kesehatan
Bakti Tunas Husada: Jurnal IImu-IImu Keperawatan, Analis Kesehatan Dan Farmasi, 13(1). https://doi.org/10.36465/jkbth.v13i1.23

Anabarwatil, E., \& Yudono, P. (2003). Keragaan Stabilitas Hasil Bawang Merah. IImu Pertanian, 10(2): 1-10.

Andriani, Y., Wahid, M., Muhammad, T., \& Mohamad, H. (2011). Antibacterial, Radical - Scavenging Activities And Cytotoxicity Properties Of Phaleria macrocarpa (Scheff.) Boerl leaves In HEPG2 Cell Lines. International Journal of Pharmaceutical Science and Research, 2(7): 1700-1706.

Arazo, M., Bello, A., Rastrelli, L., Montelier, M., Delgado, L., \& Panfet, C. (2011). Antioxidant Properties Of Pulp And Peel Of Yellow Mangosteenfruits. Emirates Journal of Food and Agriculture, 23(6): 517-524.

BPS. (2017). Sulawesi Tengah dalam Angka 2017. BPS Prop. Sulawesi Tengah, Palu.

Capelli, B., \& Cysewski, G. (2006). Astanxanthin, Natural Astanxanthin: King of The Carotenoid. Cyanotech Corporation, Hawai.

Ete, A., \& Alam, N. A. N. (2009). Karakteristik Mutu Bawang Goreng Palu Sebelum Penyimpanan. Agroland: Jurnal IImu-IImu Pertanian, 16(4). http://jurnal.untad.ac.id/jurnal/index.php/A GROLAND/article/view/262

Galeone, C., Pelucchi, C., Levi, F., Negri, E., Franceschi, S., Talamini, R., Giacosa, A., \& La Vecchia, C. (2006). Onion and garlic use and human cancer. The American Journal of Clinical Nutrition, 84(5): 10271032.

https://doi.org/10.1093/ajcn/84.5.1027

Gurav, S., Deshkar, N., Gulkari, V., a, N., \& Patil, A. (2007). Free radical scavenging activity of Polygala chinensis Linn. Pharmacologyonline, 2: 245-253.

Harborne, J. (1987). Metode Fitokimia: Penuntun Cara Modern Menganalisis tumbuhan. Ed. II. Institut Teknologi Bandung, Bandung. 
Kumalaningsih. (2006). Antioskidan Alami. Trubus Agrisarana, Surabaya.

Kumar, S., \& Pandey, A. K. (2013). Chemistry and Biological Activities of Flavonoids: An Overview. TheScientificWorldJournal, 2013: $\quad 1-16$. https://doi.org/10.1155/2013/162750

Lestario, L. N., Hastuti, P., Raharjo, S., \& Tranggono, T. (2005). Sifat Antioksidatif Ekstrak Buah Duwet (Syzygium cumini). AgriTECH, 25(1): 24-31. https://doi.org/10.22146/agritech.13374

Mardiah, N., Mulyanto, C., Amelia, A., Lisnawati, L., Anggraeni, D., \& Rahmawanty, D. (2017). Penentuan Aktivitas Antioksidan dari Ekstrak Kulit Bawang Merah (Allium ascalonicum L.) Dengan Metode DPPH. Jurnal Pharmascience, 4(2): 147-154. https://doi.org/10.20527/jps.v4i2.5768

Molyneux, P. (2003). The use of the stable radical Diphenylpicrylhydrazyl (DPPH) for estimating antioxidant activity. 26.

Nurhaeni, N., Gladys, \& Hardi, J. (2019). Uji Aktivitas Antioksidan Eksrtrak Lumut Hati (Marchantia polymorpha). KOVALEN: Jurnal Riset Kimia, 5(3): 315-321. https://doi.org/10.22487/kovalen.2019.v5.i 3.14981

Putranti, I. (2013). Skrining Fitokimia Dan Aktivitas Antioksidan Ekstrak Rumput Laut Sargassum duplicatum dan Turbinaria ornata Dari Jepara [Tesis]. Universitas Diponegoro.

Sasikumar, J., Maheshu, V., \& Jayadev, R. (2009). In Vitro Antioxidant Activity Of Methanolic Extracts Of Berberis Tinctoria Lesch. Root And Root Bark. India Journal of Herbal Medicine and Toxicology, 3 (2): 53-58.

Shekhar, T., \& Goyal, A. (2014). Antioxidant Activity by DPPH Radical Scavenging Method of Ageratum conyzoides Linn. Leaves. American Journal of Ethnomedicine, 1(4): 244-249.

Triyem. (2010). Aktivitas Antioksidan dari Kulit Batang Manggis Hutan (Garcina cf.
Bancana Miq.). [Tesis]. Universitas Indonesia, Depok.

Wijaya, A. (2011). International Journal of Pharmaceutical Science and Research. [Skripsi]. ITB, Bandung. 